\title{
Evaluasi CIPP Penerapan Permendikbud 137 dan 146 Tahun 2014 di Kecamatan Sijunjung
}

\author{
Neldawati $^{\circledR}{ }^{\bowtie}$ Yaswinda $^{1}$ \\ Pendidikan Anak Usia Dini, Universitas Negeri Padang, Indonesia(1) \\ DOI: $10.31004 /$ obsesi.v6i4.2066
}

\begin{abstract}
Abstrak
Evaluasi membuahkan pengetahuan yang relevan dengan kebijakan tentang ketidaksesuaian antara kinerja kebijakan yang diharapkan dengan apa yang benar benar dihasilkan. Tujuan artikel ini untuk mengevaluasi program Permendikbud Nomor 137 dan 146 tahun 2014 dengan metode evaluasi CIPP (Context, Input, Process, Product). Metode yang digunakan adalah deskriptif kualitatif, teknik pengumpulan data observasi wawancara dan dokumentasi. Berdasarkan hasil evaluasi yang dilakukan di Taman Kanak-kanak bahwa Permendikbud Nomor 137 dan Nomor 146 tahun 2014 mempunyai pengaruh yang sangat positif di lembaga tersebut, seperti: pedoman atau acuan lembaga dalam mengembangkan aspek perkembangan anak serta mengarahkan pendidik untuk lebih profesional. Dengan adanya Permendikbud Nomor 137 dan 146 Tahun 2014 membantu lembaga PAUD mengimplementasi proses belajar mengajar bagi anak usia dini, adapun kekurangannya adalah masih ada beberapa sekolah yang masih kesulitan mengimplementasi, seperti: sarana prasarana, latar belakang pendidikan guru, dan masih ada beberapa guru yang kesulitan memahami program pembelajaran.
\end{abstract}

Kata Kunci: evaluasi; paud; cipp.

\begin{abstract}
Evaluation produces policy-relevant knowledge about the discrepancy between the expected policy performance and what is actually produced. The purpose of this article is to evaluate the Permendikbud No. 137 and 146 of 2014 program using the CIPP (Context, Input, Process, Product) evaluation method. The method used is descriptive qualitative, data collection techniques, observation, interviews and documentation. Based on the results of the evaluation conducted in Kindergarten, the Minister of Education and Culture Regulation Number 137 and Number 146 of 2014 had a very positive influence on the institution, such as: guidelines or institutional references in developing aspects of child development and directing educators to be more professional. With the Minister of Education and Culture Number 137 and 146 of 2014 helping PAUD institutions implement the teaching and learning process for early childhood, the drawback is that there are still some schools that still have difficulty implementing, such as: infrastructure, teacher educational background, and there are still some teachers who have difficulty understand the learning program..
\end{abstract}

Keywords: evaluation; early childhood; cipp

Copyright (c) 2022 Neldawati, Yaswinda

$\triangle$ Corresponding author:

Email Address : neldawati281175@gmail.com (Padang, Indonesia)

Received 14 November 2021, Accepted 8 February 2022, Published 8 February 2022 


\section{PENDAHULUAN}

Pendidikan anak usia dini ialah pendidikan yang membantu menstimulasi aspekaspek perkembangan anak usia 0-6 tahun, usia tersebut merupakan usia yang sangat rentan dimana semua perkembangan anak berkembang dengan optimal sehingga anak memiliki kesiapan untuk pendidikan selanjutnya. Hal ini senada dengan pendapat Ayuni \& Setiawati, (2019) bahwa pendidikan anak usia dini merupakan pendidikan yang membantu anak untuk memiliki kesiapan pendidikan selanjutnya. Selain itu juga membantu menstimulasi perkembangan dan pertumbuhan anak usia dini (Hägglund \& Samuelsson, 2009; Rahayu et al., 2020).

Penyelenggaraan pendidikan anak usia dini tidak terlepas dari pedoman ataupun acuan dengan tujuan tercapainya pelaksanaan dan pembelajaran pendidikan anak usia dini (Fadlillah, 2016; Marlisa et al., 2019). Pedoman dan acuan penyelenggaraan pendidikan anak usia dini adalah Peraturan Menteri Pendidikan dan Kebudayaan nomor 137 Tahun 2014 Tentang Standar Nasional Pendidikan Anak Usia Dini dan Peraturan Menteri Pendidikan dan Kebudayaan Nomor 146 Tahun 2014 Tentang Kurikulum Pendidikan Anak Usia Dini. Permendikbud Nomor 137 Tahun 2014 berisi tentang 8 standar pendidikan anak usia dini, yaitu; Standar Tingkat Pencapaian Perkembangan Anak, Isi Proses Penilaian, Pendidikan dan Tenaga Kependidikan, Sarana dan Prasarana, Pengelolaan, dan Pembiayaan. Sedangkan Permendikbud Nomor 146 Tahun 2014 berisi tentang kurikulum 2013 pendidikan anak usia dini yang mengacu Standar Nasional Pendidikan Anak Usia Dini yang terdiri dari; kerangka dasar kurikulum, struktur kurikulum, pedoman deteksi tumbuh kembang anak, pedoman pengembangan kurikulum tingkat satuan pendidikan, pedoman pembelajaran, pedoman penilaian, dan buku-buku panduan pendidik.

Berdasarkan permasalahan di lapangan bahwa masih terdapat beberapa sekolah yang belum memenuhi standar yang telah ditetapkan dan masih terdapat guru-guru yang masih belum memahami dalam mengimplementasikan kurikulum 2013 pendidikan anak usia dini. Hal ini juga sejalan dengan penelitian Noviana et al., (2019) bahwa masih terdapat ketidaksesuaian RPPH dengan pelaksanaan pembelajaran pada hari itu. Kemudian program semester masih sama dengan gugus yang lain atau tidak ada inovasi dari sekolah. Hanya fokus pada lembar kerja dibandingkan dengan penggunaan alat permainan edukatif. Selain itu adanya perubahan kebijakan membuat para pendidik bingung untuk mengaplikasikan standard PAUD yang terdapat pada Permendikbud nomor 137 tahun 2014 (Fadlillah, 2016). Perlunya evaluasi untuk mengetahui tingkat keterlaksanaan/keberhasilan suatu program yang dibuat serta untuk mengetahui efektifitas komponen yang memiliki dampak pada program yang sedang berjalan (Gunung \& Darma, 2018). Salah satu evaluasi program yang dapat diimplementasikan Permendikbud nomor 137 dan 146 Tahun 2014 adalah Evaluasi CIPP (Context, Input, Process, Product).

Terdapat beberapa penelitian yang menggunakan evaluasi CIPP. Evaluasi CIPP (Context, Input, Process, Product) bertujuan untuk melengkapi dasar pembuatan keputusan dalam evaluasi system yang sudah direncanakan sehingga evaluasi CIPP ini cocok diimplentasikan untuk menilai program pembelajaran (Al-Shanawani, 2019; Gunung \& Darma, 2018; Warju, 2016). Hal ini senada dengan pendapat Wahyudhiana (2015) bahwa evaluasi CIPP adalah evaluasi yang mampu memperbaiki komponen dan proses sebuah program kegiatan. Penelitian yang dilakukan Yati \& Yaswinda, (2019) bahwa evaluasi CIPP digunakan untuk mengoptimalkan kelemahan penerapan Permendikbud nomor 137 tahun 2014 di lembaga kota Padang. Evaluasi CIPP bertujuan untuk mempelajari pelaksanaan pendidikan di Taman Kanak-kanak yang dilihat dari segi, yaitu; konteks, input, proses dan produk (Handoko \& Wuradji, 2015; Junanto \& Kusna, 2018; Lin \& Ching, 2012; Nuarta et al., 2020; Utsman et al., 2020). Penelitian Nurfaizah et al., (2021) menjelaskan bahwa metode CIPP sangat cocok digunakan di suatu lembaga untuk mengevaluasi program yang terdapat di lembaga PAUD. Adapun perbedaan dari penelitian ini dengan sebelumnya yaitu berfokus kepada evaluasi menggunakan CIPP dalam penerapan Permendikbud Nomor 137 dan 146 
Tahun 2014 yang diselenggarakan di TK Kecamatan Sijunjung, Sumatera Barat. Manfaat penelitian ialah untuk meningkatkan kompetensi dan terus melakukan berbagai upaya dalam memenuhi standar nasional pendidikan. Upaya tersebut dapat berupa pemenuhan standar kualifikasi guru, perbaikan dan pemenuhan sarana dan prasarana disekolah, pengadaan kegiatan yang berhubungan dengan masyarakat sekitar dalam rangka bekerja sama memajukan sekolah ataupun lembaga PAUD di Kecamatan Sijunjung, Sumatera Barat. Tujuan dari penelitian ini adalah untuk mengevaluasi program Permendikbud Nomor 137 dan 146 tahun 2014 dengan metode evalusi CIPP (Context, Input, Process, Product) di TK Kecamatan Sijunjung, Sumatera Barat.

\section{METODOLOGI}

Penelitian ini menggunakan metode penelitian deskrptif kualitatif. Model evaluasi yang digunakan adalah CIPP (Context, Input, Process, Product). Penelitian ini dilaksanakan di 10 Taman Kanak-kanak Kecamatan Sijunjung, Sumatera barat. Melibatkan 84 orang Guru TK yang terdiri dari: 21 orang guru Pegawai Negeri Sipil dan 63 orang guru Non Pegawai Negeri Sipil, dengan teknik pengambilan sampel purposive sampling. Teknik pengumpulan data yaitu wawancara struktur, observasi dan dokumentasi. Instrumen yang digunakan sudah melalui proses validasi. Teknik analisis yang dilakukan oleh peneliti adalah Analysis Interactive Model oleh Miles \& Huberman, (2005) dimana analisis yang dilakukan yaitu Data collection, Data Reduction, Data Display, dan Conclutions.

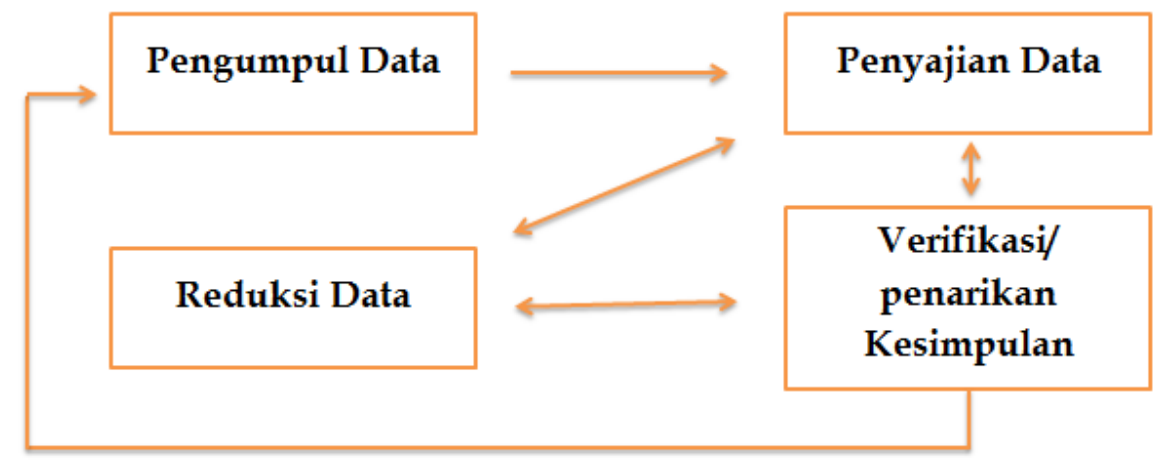

Gambar 1. Analysis Interactive Model

\section{HASIL DAN PEMBAHASAN}

Penelitian ini dilaksanakan selama 3 hari dari tanggal 9 November 2021 sampai tanggal 11 November 2021. Penelitian melakukan wawancara kepada guru TK di Kecamatan Sijunjung, Sumatera Barat. penelitian ini dilakukan peneliti sendiri. Adapun hasil yang didapatkan dalam mengevaluasi penerapan Permendikbud nomor 137 dan 146 Tahun 2014 dengan menggunakan evaluasi CIPP, yaitu:

\section{Evaluasi Context}

Evaluasi context berisi mengenai kebutuhan apa saja yang dibutuhkan dalam mencapai tujuan program yang dilaksanakan. Hal ini sependapat dengan Jaya \& Ndeot, (2019) bahwa evaluasi context ialah analisis kebutuhan yang harus dilakukan ditahap pertama pada evaluasi ini seperti kebutuhan apa saja yang diperlukan supaya tercapainya tujuan program yang dilaksanakan. Berdasarkan Hasil wawancara dan observasi yang dilakukan di Taman Kanakkanak Kecamatan Sinjujung, Sumatera Barat kebutuhan yang diperlukan adalah evaluasi lembaga apakah sudah sesuai dengan Permendikbud nomor 137 dan 146 Tahun 2014. Adapun tujuan evaluasi context adalah apakah penyelenggaraan tersebut mempunyai landasan yang kuat dan implementasi di lembaga sudah sesuai dengan Permendikbud nomor 137 dan 146 Tahun 2014 berjalan sesuai dengan acuan standard nasional PAUD dan kurikulum PAUD. 


\section{Evaluasi Input}

Pada tahap ini evaluasi yang dilakukan adalah peneliti melakukan wawancara tentang sumber daya manusia (SDM) dan sarana prasarana. Adapun hasil penelitian yang terdapat pada tabel 1 Hasil Observasi dan wawancara evaluasi Input.

Tabel 1. Hasil Observasi dan Wawancara Evaluasi Input

\begin{tabular}{|c|c|c|}
\hline No & $\begin{array}{c}\text { Hasil } \\
\text { Observasi/wawancara }\end{array}$ & Simpulan \\
\hline \multirow[t]{5}{*}{1} & SDM rata-rata dalam 1 & Dari hasil penelitian yang ditemukan bahwa dalam 1 lembaga terdiri \\
\hline & lembaga Taman & 3 orang, yaitu: 1 orang kepala sekolah, 2 guru yang merangkup \\
\hline & Kanak-kanak di Kec & sebagai operator/Tu. Ada juga 1 lembaga terdiri dari 5 orang yang \\
\hline & Sijunjung Sumatera & terdiri dari 1 orang kepala sekolah, 3 orang guru dan 1 operator/TU. \\
\hline & $\begin{array}{l}\text { Barat terdiri dari } 3-8 \\
\text { orang guru }\end{array}$ & $\begin{array}{l}\text { Di beberapa sekolah TK yang memiliki kelas atau murid banyak } \\
\text { terdiri dari } 8 \text { orang, yaitu: } 1 \text { kepala sekolah, } 6 \text { guru, dan } 1 \\
\text { operasional/TU. }\end{array}$ \\
\hline 2 & $\begin{array}{l}\text { SDM guru masih } \\
\text { kurang dan beberapa } \\
\text { latar belakang } \\
\text { pendidikan guru } \\
\text { tamatan SMA/bukan } \\
\text { jurusan PAUD }\end{array}$ & $\begin{array}{l}\text { Hasil penelitian yang dilakukan masih terdapat lembaga yang } \\
\text { kekurangan SDM ditambah lagi masih terdapat guru yang } \\
\text { backgroundnya bukan basic PAUD melainkan lulusan lain, ataupun } \\
\text { masih ada yang tamatan SMA hal ini dikarenakan memberdayakan } \\
\text { masyarakat yang ada di circle PAUD. Walaupun background guru } \\
\text { tersebut tidak relate dengan PAUD namun mereka sudah mengikuti } \\
\text { pelatihan khusus tentang PAUD (Yati \& Yaswinda, 2019). }\end{array}$ \\
\hline 3 & $\begin{array}{l}\text { Sarana prasarana } \\
\text { sudah mulai } \\
\text { memadai, walaupun } \\
\text { masih ada beberapa } \\
\text { sekolah yang masih } \\
\text { belum lengkap. }\end{array}$ & $\begin{array}{l}\text { Sebagian sekolah sudah memiliki sarana prasarana yang lengkap dan } \\
\text { memadai, baik dari alat permainan outdoor ataupun indoor. Namun } \\
\text { ada beberapa sekolah juga yang belum lengkap baik sarana } \\
\text { prasarana. }\end{array}$ \\
\hline
\end{tabular}

\section{Evaluasi Process}

Evaluasi proses yang dilakukan dalam penelitian ini adalah proses kegiatan pembelajaran di Taman Kanak-kanak Kecamatan Sijunjung, Sumatera Barat melalui Perencanaan pembelajaran yang sesuai dengan Permendikbud nomor 146 tahun 2014 tentang kurikulum pendidikan anak usia dini. Berdasarkan hasil penelitian yang dilakukan bahwa Taman Kanak-kanak sudah menggunakan kurikulum PAUD sesuai dengan pedoman Permendikbud nomor 146 Tahun 2014. Berikut ini table 2 hasil observasi/wawancara evaluasi process.

\section{Evaluasi Product}

Evaluasi produk yang dilakukan adalah mengukur, menilai ataupun menginterpretasikan capian dari program yang dilakukan. Evaluasi yang dilakukan peneliti adalah proses kegiatan pembelajaran di Taman Kanak-kanak Kecamatan Sijunjung, Sumatera Barat Standar Isi Tingkat Pencapaian Perkembangan Anak atau yang sering disebut STPPA sesuai dengan kurikulum 2013 yang diaplikasikan di Pendidikan Anak Usia Dini. STPPA meliputi Kompetensi Inti, Kompetensi Dasar, dan Lama belajar. Pelaksanaan proses pembelajaran di Taman Kanak-kanak Kecamatan Sijunjung, Sumatera Barat menggunakan STTPA sebagai acuan perkembangan anak dan menggunakan kurikulum untuk pelaksanaan pembelajaran.

Dari hasil penelitian yang didapatkan bahwa evaluasi CIPP penerapan Permendikbud Nomor 137 dan Nomor 146 tahun 2014 yang dilaksanakan di Taman Kanak-kanak Kecamatan Sijunjung, Sumatera Barat dari segi evaluasi input adalah untuk sumber daya manusia dalam 1 sekolah terdiri dari 3-8 orang, namun masih ada beberapa tenaga pengajar yang memiliki latar belakang pendidikan bukan PAUD melainkan lulusan lain dan masih ada juga guru yang 
pendidikan terakhir SMA (Yati \& Yaswinda, 2019). Sarana dan prasarana yang ada di Taman Kanak-kanak Kecamatan Sijunjung memiliki fasilitas yang lengkap, seperti: alat permainan edukatif, alat permainan outdoor ataupun indoor. Namun masih ada sekolah yang belum memiliki sarana dan prasarana yang lengkap, dikarenakan factor keuangan. Hal ini sejalan dengan hasil penelitian (Wulandari et al., 2018) bahwa evaluasi CIPP yang digunakan pada evaluasi input PAUD HI dari segi sarana dan prasarana belum terpenuhi yang disebabkan dari segi keuangan.

Tabel 2. Hasil Observasi/wawancara Evaluasi Process

\begin{tabular}{|c|c|c|}
\hline No & Hasil Observasi/wawancara & Simpulan \\
\hline 1 & $\begin{array}{l}\text { Semua TK Kec Sijunjung, } \\
\text { Sumatera Barat } \\
\text { mengembangkan ke-enam } \\
\text { aspek perkembangan anak } \\
\text { sesuai dengan kurikulum } 2013 \\
\text { yang digunakan }\end{array}$ & $\begin{array}{l}\text { Semua TK Kec Sijunjung, Sumatera Barat } \\
\text { mengembangkan semua aspek perkembangan anak usia } \\
\text { dini, yaitu; nilai agama dan moral, fisik-motorik, kognitif, } \\
\text { bahasa, social emosional, dan seni yang sesuai dengan } \\
\text { pedoman kurikulum PAUD Permendikbud nomor } 146 \\
\text { Tahun } 2014 \text { dan menggunakan KI dan KD yang } \\
\text { merupakan gambaran STPPA. }\end{array}$ \\
\hline 2 & $\begin{array}{l}\text { Waktu kegiatan pembelajaran } \\
\text { disesuaikan dengan dengan isi } \\
\text { yang tertuang dalam } \\
\text { Permendikbud no } 146 \text { tshun } \\
2014\end{array}$ & $\begin{array}{l}\text { Waktu dalam kegiatan pembelajaran di TK disesuaikan } \\
\text { dengan lama belajar dalam kurikulum PAUD yaitu; satu } \\
\text { minggu, satu semester, serta satu tahun. Selain itu juga } \\
\text { durasi waktu kelompok usia 4-6 tahun } 900 \text { menit } \\
\text { perminggu. }\end{array}$ \\
\hline 3 & $\begin{array}{l}\text { Menggunakan kerangka acuan } \\
\text { pembelajaran di TK Kecamatan } \\
\text { Sijunjuang Sumatera Barat; } \\
\text { modul pembelajaran dan draf; } \\
\text { jadwal kegiatan; format } \\
\text { penilaian pembelajaran }\end{array}$ & $\begin{array}{l}\text { Kerangka yang digunakan adalah perencanaan } \\
\text { pembelajaran, seperti; Program Tahunan (PROTA), } \\
\text { Program Semester (PROSEM), Program Perencanaan } \\
\text { Pembelajaran Mingguan (RPPM), Program Perencanaan } \\
\text { Pembelajaran Harian (RPPH), walaupun ada sebagian } \\
\text { guru yang masih bingung dalam implementasi program } \\
\text { tersebut. Namun walaupun mereka bingung guru-guru } \\
\text { tetap membuat perencanaan dengan bimbingan guru } \\
\text { yang lain. Setiap sekolah mempunyai SOP layanan } \\
\text { pembelajaran anak. } \\
\text { Pembelajaran diawali dengan kegiatan pembuka, kegian } \\
\text { inti dan kegiatan penutup dan tidak lupa juga } \\
\text { pembelajaran diiringi dengan bernyanyi dan } \\
\text { menggunakan konsep belajar sambil bermain. Evaluasi } \\
\text { dilakukan dengan cara penilaian harian, bulanan, } \\
\text { semester berupa laporan perkembangan anak. Adapun } \\
\text { penilaian anak dilakukan dengan catatan anekdot, hasil } \\
\text { karya anak, rating scale. }\end{array}$ \\
\hline
\end{tabular}

Adapun hasil evaluasi proses pada penelitian ini adalah Semua Semua TK Kec Sijunjung, Sumatera Barat mengembangkan semua aspek perkembangan anak usia dini, yaitu; nilai agama dan moral, fisik-motorik, kognitif, bahasa, social emosional, dan seni yang sesuai dengan pedoman kurikulum PAUD Permendikbud nomor 146 Tahun 2014 dan menggunakan KI dan KD yang merupakan gambaran STPPA. Waktu dalam kegiatan pembelajaran di TK disesuaikan dengan lama belajar dalam kurikulum PAUD yaitu; satu minggu, satu semester, serta satu tahun. Selain itu juga durasi waktu kelompok usia 4-6 tahun 900 menit perminggu. Kerangka yang digunakan adalah perencanaan pembelajaran, seperti; Program Tahunan (PROTA), Program Semester (PROSEM), Program Perencanaan Pembelajaran Mingguan (RPPM), Program Perencanaan Pembelajaran Harian (RPPH), walaupun ada sebagian guru yang asih bingung dalam implementasi program tersebut. Namun walaupun mereka bingung guru-guru tetap membuat perencanaan dengan bimbingan guru yang lain. Setiap sekolah mempunyai SOP layanan pembelajaran anak. Pembelajaran diawali dengan kegiatan 
pembuka, kegiatan inti dan kegiatan penutup dan tidak lupa juga pembelajaran diiringi dengan bernyanyi dan menggunakan konsep belajar sambil bermain. Evaluasi dilakukan dengan cara penilaian harian, bulanan, semester berupa laporan perkembangan anak. Adapun penilaian anak dilakukan dengan catatan anekdot, hasil karya anak, rating scale. Sedangkan evaluasi produk yaitu proses kegiatan pembelajaran di Taman Kanak-kanak Kecamatan Sijunjung, Sumatera Barat Standar Isi Tingkat Pencapaian Perkembangan Anak atau yang sering disebut STPPA sesuai dengan kurikulum 2013 yang diaplikasikan di Pendidikan Anak Usia Dini. STPPA meliputi Kompetensi Inti, Kompetensi Dasar, dan Lama belajar. Pelaksanaan proses pembelajaran.

Hasil penelitian ini mempunyai kesamaan dengan penelitian (Wulandari et al., 2018) bahwa penelitian tersebut menggunakan pendekatan CIPP dimana hasil penelitian yang didapatkan sesuai dengan kriteria, seperti : 1) evaluasi input sudah baik, namun sarana dan prasarana belum terpenuhi hal ini disebabkan dari segi keuangan. 2) evaluasi proses sudah berjalan dengan baik dan sesuai dengan kriteria yang ditunjukkan bahwa pembelajaran di PAUD diawali dengan perencanaan pembelajaran (RPS, RPPM, dan RPPH). 3) Namun pada evaluasi produk memiliki perbedaan yaitu kegiatan pembelajaran yang berdasarkan STTPA, sedangkan penelitian Wulandari et al., (2018)melihat pemenuhan kebutuhan esensial anak, seperti: kesehatan, stimulasi, pola asuh yang digunakan, dan lain-lain.

Selain itu hasil penelitian (Yati \& Yaswinda, 2019) mempunyai kesamaan pada hasil penelitian bahwa pelaksanaan Permendibud Nomor 146 dan Nomor 137 tahun 2014 secara universal belum tercapai dengan optimal, salah satunya sarana prasarana yang kurang memadai sehingga tidak aman digunakan anak usia dini. Adapun hasil penelitian (Yuliani Nurani et al., (2019) bahwa pelaksanaan evaluasi CIPP memiliki perbedaan pada hasil penelitian yaitu peneliti berfokus kepada evaluasi Permendikbud Nomor 146 dan Nomor 137 Tahun 2014, sedangkan penelitian Yuliani Nurani et al., (2019) pelaksanaan pembelajaran di Taman Kanak-kanak adapun hasil penelitian yang didapatkan adalah komponen pembelajaran yang dilakukan di Taman-kanak-kanak secara keseluruhan berjalan dengan efektif. Pelaksanaan pembelajaran mengacu pada silabus seperti Rencana Kegiatan Harian (RKH).

Hasil penelitian (Basaran et al., 2021) bahwa evaluasi CIPP program pendidikan PAUD, yaitu: 1) adanya kekurangan dari segi infrastrukur fisik bahwa bangunan sekolah tidak sesuai dengan standard yang ditentukan, 2) terdapat guru yang memiliki tingkatan pendidikan yang lebih rendah, 3) sarana dan prasarana tidak memadai, 4) masih terdapat guru yang bingung dengan materi yang akan disampaikan dalam pembelajaran. Dari hasil penelitian tersebut ada beberapa point yang memiliki kesamaan dengan hasil penelitian yaitu dari segi sarana/prasarana, latar belakang pendidikan guru, dan terdapat guru yang bingung dengan program pelaksanaan pembelajaran. Adapun implikasi dalam penelitian ini yaitu adanya evaluasi CIPP Permendikbud Nomor 146 dan Nomor 137 Tahun 2014 selain sebagai acuan atau pedoman di lembaga PAUD, namun masih terdapat kekurangan, seperti: masih ada beberapa sekolah yang kurang lengkap sarana dan prasarana, tingkat dan latar pendidikan guru bukan lulusan PAUD, masih terdapat guru yang bingung dalam mengimplementasi program pembelajaran.

\section{SIMPULAN}

Evaluasi CIPP (Context, Input, Process, Product) dapat digunakan untuk menilai program atau standard yang ada di lembaga PAUD seperti Permendikbud Nomor 146 dan 137 Tahun 2014. Permendikbud Nomor 137 dan Nomor 146 tahun 2014 mempunyai pengaruh yang sangat positif di lembaga tersebut, seperti: pedoman atau acuan lembaga dalam mengembangkan aspek perkembangan anak serta mengarahkan pendidik untuk lebih profesional. Meskipun penerapan Permendikbud Nomor 137 dan 146 Tahun 2014 mampu menjadi pedoman, namun masih terdapat sekolah yang belum memenuhi standard tersebut. Hal ini dipengaruhi dari beberapa factor internal dan eksternal di lembaga PAUD. 


\section{UCAPAN TERIMA KASIH}

Mengucapkan terima kasih kepada pihak yang terlibat pada penelitian ini. Terutama para pendidik di Taman Kanak-kanak Kecamatan Sijunjung, Sumatera Barat yang sudah berpartisipasi. Semoga artikel yang ditulis memberikan manfaat untuk pihak-pihak terkait khususnya pendidikan anak usia dini.

\section{DAFTAR PUSTAKA}

Al-Shanawani, H. M. (2019). Evaluation of Self-Learning Curriculum for Kindergarten Using Stufflebeam's CIPP Model. SAGE Open, 9(1), 215824401882238. https:// doi.org/10.1177/2158244018822380

Ayuni, D., \& Setiawati, F. A. (2019). "Kebun Buah" Learning Media for Early Childhood Counting Ability Despa. Jurnal Obsesi : Jurnal Pendidikan Anak Usia Dini, 3(1), 1-9. https://doi.org/10.31004/obsesi.v3i1.128

Basaran, M., Dursun, B., Gur Dortok, H. D., \& Yilmaz, G. (2021). Evaluation of Preschool Education Program According to CIPP Model. Pedagogical Research, 6(2), em0091. https:// doi.org/10.29333/pr/9701

Fadlillah, M. (2016). Komparasi Permendikbud Nomor 137 Tahun 2014 Dengan Permendiknas Nomor 58 Tahun 2009 Dalam Pembelajaran Paud. Jurnal INDRIA (Jurnal Ilmiah Pendidikan Prasekolah Dan Sekolah Awal), 1(1), 42-53. https:// doi.org/10.24269/jin.v1n1.2016.pp42-53

Gunung, I. N., \& Darma, I. K. (2018). Implementasi Evaluasi Program Model CIPP Untuk Mengukur Evektifitas Pelaksanaan Pembelajaran di Politeknik Negeri Bali.

Hägglund, S., \& Samuelsson, I. P. (2009). Early childhood education and learning for sustainable development and citizenship. International Journal of Early Childhood, 41(2), 49-63. https:// doi.org/10.1007/BF03168878

Handoko, H., \& Wuradji, W. (2015). Evaluasi program pendidikan dan pengembangan anak usia dini (PPAUD) di Kabupaten Kulon Progo. Jurnal Pendidikan Dan Pemberdayaan Masyarakat, 2(1), 24. https:// doi.org/10.21831/jppm.v2i1.4841

Jaya, P. R. P., \& Ndeot, F. (2019). Penerapan Model Evaluasi Cipp Dalam Mengevaluasi Program Layanan Paud Holistik Integratif. PERNIK: Jurnal Pendidikan Anak Usia Dini, 1(1), 10. https:/ / doi.org/10.31851/pernik.v1i01.2622

Junanto, S., \& Kusna, N. A. A. (2018). Evaluasi Program Pembelajaran di PAUD Inklusi dengan Model Context, Input, Process, and Product (CIPP). Inklusi, 5(2), 179. https:// doi.org/10.14421/ijds.050202

Lin, H. F., \& Ching, M. J. (2012). Managing the Taiwan kindergarten evaluation system. International Journal of Research Studies in Management, 1(1), 77-84. https:// doi.org/10.5861/ijrsm.2012.v1i1.53

Marlisa, L., Studi, P., Islam, P., Usia, A., \& Metro, U. M. (2019). Pembelajaran Pendidikan Anak Usia Dini (Telaah Dalam Permendikbud 146 Tahun 2014 ) Terhadap Kurikulum Pendidikan Anak Usia Dini. 6(2), 136-145.

Miles, M., \& Huberman, M. (2005). No Qualitative Data Analysis (Terjemah). UI Press.

Noviana, D., Nisa', T. F., \& Karim, M. B. (2019). Tingkat Pengetahuan Guru PAUD tentang Kurikulum 2013. Jurnal PG-PAUD Trunojoyo : Jurnal Pendidikan Dan Pembelajaran Anak Usia Dini, 6(2), 114-124. https:// doi.org/10.21107/pgpaudtrunojoyo.v6i2.6153

Nuarta, I. G., Yudana, I. M., \& Natajaya, N. (2020). Studi Evaluatif Pelaksanaan Program Pendidikan TAMAN Kanak-Kanak (TK). Mimbar Ilmu, 25(1), 98. https:// doi.org/10.23887/mi.v25i1.24481

Nurfaizah, Yuniarti, \& Sukiman. (2021). Evaluasi Kurukulum dengan Model. Jurnal Riset Golden Age PAUD UHO, 4(1).

Rahayu, H., Yetti, E., \& Supriyati, Y. (2020). Meningkatkan Kreativitas Anak Usia Dini melalui Pembelajaran Gerak dan Lagu. Jurnal Obsesi : Jurnal Pendidikan Anak Usia Dini, 5(1), 832-840. https://doi.org/10.31004/obsesi.v5i1.691 
Utsman, U., Fakhruddin, F., \& Kisworo, B. (2020). Evaluation of Quality Early Childhood Education Program Services Using CIPP Model. Proceedings of the Proceedings of the 5th International Conference on Science, Education and Technology, ISET 2019, 29th June 2019, Semarang, Central Java, Indonesia. https://doi.org/10.4108/eai.29-6$\underline{2019.2290467}$

Wahyudhiana, D. da. (2015). Model Evaluasi Program Pendidikan. Islamadina, XIV(1), 1-28.

Warju, W. (2016). Educational Program Evaluation using CIPP Model. Innovation of $\begin{array}{llll}\text { Vocational Technology } \quad \text { Education, } & \text { 36-42. }\end{array}$ https://doi.org/10.17509/invotec.v12i1.4502

Wulandari, H., Supriyati, Y., \& Jalal, F. (2018). Evaluation of Holistic Integrative Program in Early Childhood Education and Development (PAUD HI). International Journal of Multidisciplinary and Current Research, 3(June), 406-412.

Yati, F., \& Yaswinda, Y. (2019). Penerapan Model Evaluasi CIPPO dalam Mengevaluasi Penyelenggaraan Lembaga PAUD. Jurnal Obsesi : Jurnal Pendidikan Anak Usia Dini, 4(1), 30. https:// doi.org/10.31004/obsesi.v4i1.238

Yuliani Nurani, Y., Nurani, Y., Hartati, S., \& Pratiwi, N. (2019). Evaluation of Learning Center in Kindergarten. Proceedings of the 5th International Conference on Education and Technology (ICET 2019), 382(Icet), 535-539. https://doi.org/10.2991/icet-19.2019.135 